UNIO - EU Law Journal. Vol. 6, No. 2, July 2020, pp 49-56.

®2020 Centre of Studies in European Union Law

School of Law - University of Minho

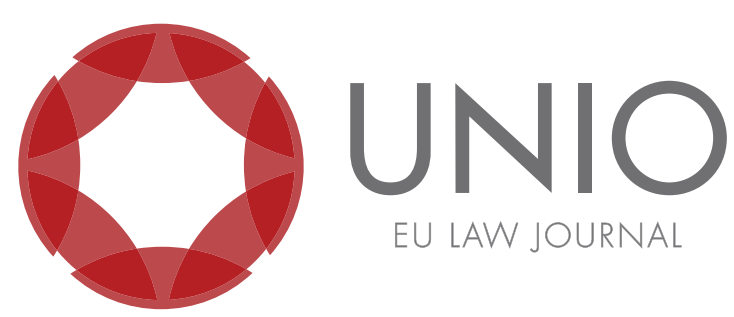

\title{
The justification of the means by the ends in the context of indirect taxation in COVID-19 times - a real catastrophe?
}

\author{
Andreia Barbosa*
}

ABSTRACT: The terms in which VAT and customs duties are carried out in the Member States of the European Union are an integral part of the regulatory framework that arises from the European Institutions, specially designed to guarantee the functioning of the Single Market, as a dimension underlying the European project. In the context of COVID-19 - in which the imports of goods necessary for the respective combat and prevention have known and are of particular practical importance -, the Union's intervention with regard to the taxation of such imports was (and is) necessary to guarantee an appropriate response and garner effective action by Member States. This answer, at least in the context of the indirect taxation, could not be made in several voices, but rather in a single way, in front of a normative plan that, in the case of VAT, is barmonised and which, in the case of customs duties, is uniformed, in a tax integration that seems to move (or should move) towards fullness. Among the various solutions put forward by the Union, of a tax nature, in the pandemic situation, one stands out in particular, of a substantive scope (although others, of an adjective character, having been adopted), which is related to the customs relief and the VAT exemption on the import of necessary goods to combat the effects of COVID-19 in 2020. The highlight is essentially justified by reasons related to its (i) ratio legis, (ii) the corresponding teleology and also (iii) the terms in which Portugal welcomed and developed the measure. This paper will focus on each of these reasons, under the pretext of which the dimensions deemed worthy of special reflection will be addressed, in a perspective that essentially starts from proportionality considerations, aimed at assessing whether the ends justify the means.

KEYWORDS: value added tax - customs duties - tax benefits - Single Market.

${ }^{*} \mathrm{PhD}$ candidate at the University of Minho. Invited assistant professor at the University of Minho. 


\section{The qualification of the pandemic as a catastrophe}

The relief from customs duties and the exemption from VAT were established, firstly, by Commission Decision (EU) 2020/491, of 3 April 2020, and, subsequently (before the end of the period established therein for granting such tax benefits -31 July 2020), by Commission Decision (EU) 2020/1101, of 23 July 2020 (which grants the relief and exemption until 31 October 2020). Such Decisions arose through the provisions of Articles 76 of Council Regulation (EC) no. 1186/2009 and 53 of Directive 2009/132/EC (which corresponds, internally, by transposition, to Article 51 of Decree-Law no. 31/89), under which the granting of the relief and exemption is subject to the decision of the European Commission, where, if necessary, the scope and conditions for applying the relief and exemption are fixed.

The removal of taxation is then returned to imported goods that, in general terms, are intended for free distribution by people affected by COVID-19 or exposed to this risk, as well as to people who participate in the fight against COVID-19, and it is justified precisely because this pandemic is qualified as a catastrophe for legal and tax purposes, within the meaning of Chapter XVII, Section C, of Regulation (EC) no. 1186/2009 (on the establishment of the Community customs relief regime) and Title VIII, Chapter 4, of Directive 2009/132/EC (on the VAT exemption for certain definitive imports of goods). Therefore, catastrophe appears as a ratio legis for such measures.

It happens, however, that none of the aforementioned diplomas conceptually densifies catastrophe, so the understanding that the pandemic COVID-19 is catastrophic appears as justified, it seems to us, not because of its special contours, but because of the fact that such qualification arises as the only legally-normatively permissible way to remove taxation from transactions that do not deserve to be encumbered, to protect extra-fiscal and supra-state public interests that are considered to be superior to the taxation that they prevent. Noting, therefore, that legislation specifically designed to regulate customs and VAT taxation is silent on the granting of reliefs and exemptions in the specific case of a pandemic or other phenomena capable of affecting, particularly and seriously, public health, the qualification of the pandemic as a catastrophe appears to be the only legally suitable way to achieve this purpose of tax relief. On the other hand, the tax benefits granted can be found in the respective normative legal instruments appropriated to the discipline in question, as real legislative acts: the relief is granted through Regulation and the VAT exemption through a Directive.

Although this solution can be seen as far-fetched, the truth is that the absence of normative densification of catastrophe allows the concept to be given sufficient (and necessary) elasticity to adapt it to unpredictable and very serious factual contexts that the legislator, at the time of normative creation, could not, with high intensity, describe. Even if doubts are raised as to the conformity of this minimum legal-normative intensity with constitutional requirements of legality and legal certainty when it comes to essential elements of taxes (such as, precisely, tax benefits), it is the extensive interpretation (even if distant, in particular, in the field of VAT exemptions in view of the distortions to neutrality that may result from it) which appears to be adequate and necessary in front of the purpose to be achieved ${ }^{1}$. This is, therefore, one of the cases in

\footnotetext{
${ }^{1}$ We have renewed the framework of COVID-19 as a catastrophe to extensive interpretation and not to analogue integration, considering that the aforementioned unpredictable and serious factual situation is prescribed by law instruments, which aimed at customs taxation and VAT. It is, however, a prediction that is silent on the terms of its concrete applicability.
} 
which the ends (tax exemption) justify the means (extensive interpretation of essential elements to taxation).

\section{The loss of own resources of the European Union}

In addition to the other harmful effects of the pandemic, its negative impact on the financial domain is evident. It is precisely in contexts of financial crisis that the importance of tax matters is recognised, from the outset through the eventual necessary tax adjustments, which can mean an increase in taxation (and a decrease in expenditure).

However, both customs duties (managed by Member States) and a percentage of VAT (charged by Member States) ${ }^{2}$ represent the European Union's own resources, under the terms of Decision 2014/335/EU, of 26 May 2014, EURATOM. ${ }^{3}$ The relief from customs duties and the exemption from VAT will, therefore, mean a drop in revenues destined for the European Union, which enters into a collision course with the particular relevance that such resources represent in crisis contexts.

According to the data contained in the General Budget of the European Union for the year 2020, ${ }^{4}$ total revenues would be expected to reach an amount of $€ 153$ 566205 917. Traditional own resources (including customs duties and levies in the sugar sector) would represent $14.43 \%$ ( $€ 22156900000$ ) of the financing of the 2020 Budget, and the VAT resource would represent 12.34\% (€ 18945245 250). In view of the implemented tax avoidance measures and in view of the sharp reduction in international trade operations (imports and exports), ${ }^{5}$ the General Budget for 2021, despite establishing an increase in total revenues to $€ 163515102887$, provides that traditional own resources account for $10.77 \%$ ( $€ 17605700000$ ) of the financing of the 2020 budget, and the VAT resource would represent 10.99\% (€ 17967491250 ).

However, the reduction in customs resources can also be enhanced by other normative instruments that may undermine the collection of customs duties and which include, inter alia, the repayment of the remission based on equity that the "COVID-19 situation" is, theoretically, capable of generating. This is a possibility that, in practical terms, will always depend on a measurement made on a case-by-case basis, considering that customs legislation (in particular, Article 120 of the Union Customs Code) does not refer to the COVID-19 pandemic. Therefore, it will be necessary to assess the different effects that the pandemic has in relation to different economic operators, according to

\footnotetext{
${ }^{2}$ A uniform rate of $0.30 \%$ is applied (except for Germany, Netherlands and Sweden, for which the mobilization rate for the 2014-2020 period was fixed at 0.15\%), which is levied on the VAT base and which is uniform across the Union, although the base to be taken into account for the application of the mentioned rate is limited to $50 \%$ of the Gross National Income - GNI - of each Member State. This limitation was fixed in order to prevent that States financially less prosperous support, disproportionately, the payment, in view of their respective contributory capacity, considering that consumption and VAT tend to represent a larger percentage of the GNI of each less prosperous Estate.

${ }^{3}$ It is the Council Regulation (EU, Euratom) no. 608/2014 of 26 May 2014, that establishes the measures for the system of own resources of the European Union. The Member States are financially responsible for any losses of traditional own resources owing to their administrative errors. For more developments about this subject, vide José Rijo, Direito Aduaneiro da União Europeia. Notas de enquadramento normativo, doutrinário e jurisprudencial (Coimbra: Almedina, 2020), 244.

${ }^{4}$ The General Budget of the European Union for the year 2020 is available at: https:/ / eur-lex.europa. eu/legal-content/PT/TXT/PDF/?uri=CELEX:32020B1078\&from=EN, accessed October 6, 2020.

${ }^{5}$ The specific terms of the decrease in operations can be checked in detail in EUROSTAT. For a comparison between the years 2019 and 2020, vide http://appsso.eurostat.ec.europa.eu/nui/ submitViewTableAction.do, accessed October 6, 2020.
} 
their respective capacity and preparation to protect themselves against situations of this nature, ${ }^{6}$ which certainly bring negative consequences (possibly unavoidable) and that are not attributable to mismanagement or, even less, to fraudulent intentions of economic operators.

The loss of own resources (although it cannot be assumed as purpose, but as an effect) is thus justified, given the need to facilitate, by removing tax obstacles, international trade operations, that are relevant in combating and preventing COVID-19. It is an outcome that well reflects the terms in which the European Union's performance, in a tax context, is capable of surpassing revenue collection purposes, in a conception that assumes the pursuit of the public interest as being returned, first, to the protection of legal assets (in this case, a fundamental legal asset: health). In any case, it is important to highlight the evident relevance that public financial sustainability is aware of, and it should be maintained (if not enhanced) in the post-pandemic and in the post-crisis. We must not forget the right to face the future with optimism, in light of the principle of intergenerational equity.

\section{The adoption of concrete internal measures}

The European Union's intervention in tax matters is shaped by the principle of Subsidiarity (Article 5 (3) of the Treaty on European Union): the European Union only acts (normatively) when two elements are brought together: one, negative - when the legal discipline created by the Member States is insufficient to meet the European project - another, of a positive nature - when the European Union's ability to better pursue the objectives of the Treaties in a given case is manifest.

Specifically, with regard to indirect taxation, the level of legal-normative approximation already achieved is evident, in an effect attained through the normative instruments adopted for the discipline of customs taxation and regarding VAT: Regulations and Directives, respectively. Harmonisation (or even uniformity, in the case of part of the customs legal regime) is justified by the need to ensure the establishment and functioning of the Internal Market and to avoid distortions of competition, in accordance with the provisions of Article 113 of the Treaty on the Functioning of the European Union. Such objectives - essential to the achievement of European integration - are not compatible with legal regimes that give different tax treatment to commercial transactions between Member States and between them and third countries. In fact, "one of the purposes of European integration has been to ensure that the benefits of trade do not come at the expense of regulatory races to the bottom". 'The scope for the special adoption of internal measures in the context of customs duties and VAT is, thus, limited.

From this framework, we will look at the terms in which, internally, the measures implemented by the Union may have a concrete reflection, in an analysis that will be centered on the Portuguese tax system, but which is understood and is expected to be valid for other quadrants in which the principle of legality is used to support normative action.

In customs matters, as was said, the legal regime possesses a considerable level of uniformity, leaving only the Member States with legislative competence in terms of

\footnotetext{
${ }^{6}$ Vide "Guidance on Customs issues related to the COVID-19 emergency", European Commission, available at: https://ec.europa.eu/taxation_customs/covid-19-taxud-response/guidance-customsissues-related-covid-19-emergency_en, accessed October 6, 2020.

${ }^{7}$ Cf. Kevin O’Rourke, A short bistory of Brexit (London: Pelican Book, 2019), 91.
} 
administrative and jurisdictional reaction against acts of the Customs Authorities and in matters of customs offenses and crimes. In this sense, the relief granted did not know (because it is not necessary), in the internal scope, any normative development, only finding the Portuguese Customs Authority reproducing the terms of the referred Commission Decisions or clarifying issues related to customs procedures to adopt in the face of the pandemic, ${ }^{8}$ and an Order no. 139/2020-XXII, of April 3, 2020, by the Secretary of State for Tax Affairs, which identifies the entities that, specifically in the internal context and in light of the Decision, benefit from the relief (and VAT exemption). ${ }^{9}$

As far as VAT is concerned, the national intervention went further than the Union Decisions, having been granted an exemption that did not result from the intervention of the European Union, in the terms described. ${ }^{10}$ It is not questioned, of course, the goodness of the measure or the end to be reached through it, but the terms from which it emerged, which raise, in our view, doubts about its constitutionality.

In particular, on March 24 (before the first of the Commission Decisions had been issued), Order no. 122/2020-XXII, of the Secretary of State for Tax Affairs, ${ }^{11}$ was issued, pursuant to which determined that (i) "the exemption provided for in article 15, paragraph 10, point a) of the VAT Code, is also applicable to the transmission of goods free of charge to the State, to private institutions of social solidarity and to non-profit non-governmental organizations, for later making available to people in need, even if they remain in the ownership of those bodies (...)", and that (ii) "for the purposes of article 15, paragraph 10 , point a) of the VAT Code also consider people in need to be those who are receiving health care in the current pandemic context, who are considered victims of catastrophe".

With regard to the application of this precept, it should be noted that, in the wording of the VAT Code, "transfers of goods free of charge" are concerned, so we are faced with economic operations outside the field of VAT (which focuses on onerous operations). However, the granting of an exemption for such operations, whose assets are subsequently allocated to the relevant purposes indicated therein, is justified, taking into account the purposes of public interest to be achieved in the distribution of

\footnotetext{
${ }^{8}$ Vide ofício-circulado no. 15758, April 15, 2020, available at: https:/ /info-aduaneiro.portaldasfinancas.gov. pt/pt/legislacao_aduaneira/oficios_circulados_doclib/Documents/Oficio_circulado_15758_2020. pdf; ofício-circulado no. 15760, April 15, 2020, available at https://info-aduaneiro.portaldasfinancas.gov. pt/pt/legislacao_aduaneira/oficios_circulados_doclib/Documents/Oficio_circulado_15760_2020. pdf; ofício-circulado no. 15762, April 22, 2020, available at https://info-aduaneiro.portaldasfinancas. gov.pt/pt/legislacao_aduaneira/oficios_circulados_doclib/Documents/Of\%C3\%ADcio_ circulado_15762_2020.pdf, accessed October 6, 2020.

9 In particular, such benefits benefit State bodies, which include, for this purpose: the State, autonomous regions and local authorities, as well as any of their services, establishments and bodies, even if personalized, including institutes public; establishments and health units that are part of the National Health Service (NHS), including those that take the legal form of public business entities; other establishments and health units in the private or social sector, as long as they are inserted in the national plan of the NHS to combat the virus COVID-19, having this obligation contracted with the Ministry of Health. They also benefit entities with charitable or philanthropic purposes previously approved for this purpose by the Tax and Customs Authority.

${ }^{10}$ Other measures were also adopted, essentially related to the fulfilment of ancillary obligations, which we will not pay attention to here. For the full list of the tax measures adopted in Portugal, in terms of VAT, vide https://info.portaldasfinancas.gov.pt/pt/apoio_contribuinte/COVID_19/ Medidas_Fiscais_e_\%20Aduaneiras/Paginas/IVA.aspx, available at October 6, 2020.

${ }^{11}$ The order no. 122/2020-XXII is available at: https://info.portaldasfinancas.gov.pt/pt/informacao_ fiscal/legislacao/Despachos_SEAF/Documents/Despacho_SEAF_122_2020_XXII.pdf, accessed October 6, 2020.
} 
these assets (which, in fact, can be any). The exemption provided for here interrupts the successive VAT settlement chain at all stages of the economic circuit, without preventing, however, the recovery of the input tax. If VAT is a tax that normally applies to all phases of that circuit, it would be expected that in all transmissions the tax would be paid "forward" of the tax due. ${ }^{12}$

Well, the aforementioned determinations, which lasted during the emergency period in Portugal motivated by the pandemic, will have had as a support, according to the text of the Order "in the principles of systematic coherence and neutrality". Better contextualising, in time, the emergence of the aforementioned Order, we are faced with a performance that arose after, on March 20, 2020, the European Commission addressed a note to the General Directors of the Tax and Customs Administrations of the Member States (and of the United Kingdom), clarifying what would be the exceptional tools available to assist disaster victims. Among such instruments, the provisions of the aforementioned Articles 51 to 57 of Directive 2009/132/EC and 49 to 55 of Decree-Law no. 31/89, appeared as a possibility, being certain, however, that, in addition to the exemption provided for there being dependent on a decision by the Commission (which, at the date of issuance of the Order, did not yet exist), ${ }^{13}$ it was not shown to be applicable in cases where identical operations were at issue, carried out in the national territory. It was in this sense that it was decided to determine as exempt free transmissions of goods destined to be distributed by needy people (victims of the catastrophe), even if these remain in the property of the State, private institutions of social solidarity or non-governmental non-profit organisations (entities in relation to whom the transmissions must have been made). Thus, in the Order, it was assumed that the legislator, in such transfers (those that were already provided in Article 15, paragraph 10, point a), of the VAT Code), (i) referred to those that occur in the national territory (excluding, therefore, intra-community transfers of goods and imports), and that (ii) was intended to refer to any goods. The precept was changed, and it was added that these transfers are exempt even if the transferred goods are the property of the person who carries out the operations. It is in this sense that we are led to consider that this is a new exemption.

We cannot ignore the introductory paragraphs that make up the Order under analysis, and that justify the resulting determinations, two of which expose the following: "Considering that those legal provisions [articles 51 to 57 of Directive 2009/132/EC] provide for the application of a VAT exemption to goods imported by State agencies whether intended to be distributed free of charge to victims of disasters or intended to be made available to victims of such disasters free of charge, remaining the property of the bodies in question", ${ }^{14}$ and "Considering that the simple application of the provisions of articles 51 to 57 of Council Directive 2009/132 / EC of 19 October 2009, may call into question the principle of VAT neutrality for not apply in the same way to identical operations carried out in the national territory". Now, Article 15 (10) (a) of the VAT Code ${ }^{15}$ which in the Order is considered to establish a regime that

\footnotetext{
${ }^{12}$ Vide João Ricardo Catarino, in the comment to no. 10 of Article $15 .^{\circ}$ of the VAT CODE, in RITI: notas e comentários, coord. Clotilde Celorico Palma e António Carlos dos Santos (Coimbra: Almedina, 2014), 218 e 219.

${ }^{13}$ However, under Article 51 (2) of Decree-Law no. 31/89, it is allowed, in the period of notification of the Commission's decision, the import of goods for the benefit of victims of catastrophes, suspending the application of VAT upon the commitment of the importing entity to proceed to the respective payment, in the case the exemption is not granted.

${ }^{14}$ Our interpolation.

${ }^{15}$ The regime of paragraph 10 of Article 15 (paragraphs a) and b) was added by Law no. 64-A/2008,
} 
"can be classified as an exceptional instrument to promote aid to victims of the pandemic", in fact leads to the exemptions that benefit operations related to suspensive regimes, so it is questionable the use of this precept when in question are operations carried out in the national territory. In any case, the meaning of the determination is understood, considering that, in the case of imports, the exemption was already the result of the provisions of Directive 2009/132/EC and Decree-Law no. 31/89, whose applicable precepts (Articles 51 (b) and 49 (1) (b), respectively) already emphasise the possibility that the exemption applies even if the ownership of the goods remains with the bodies concerned.

Although it is understood that this is not a new exemption, but rather a change to an existing exemption, or even an extensive interpretation of the precept, the problem lies in the fact that such "determination" was established through the use of a simple Order, which focuses on the essential subject of a tax (in this case, tax benefits), which must be disciplined, under the terms of Articles 103, paragraph 2, and 165, paragraph 1, i), of the Constitution of the Portuguese Republic (CPR), and Article 8, paragraph 1, of the General Tax Law, by the Law of the Parliament or by authorised Government Decree-Law. The Secretary of State for Tax Affairs did not have the competence to discipline on the matter, nor could it have been overturned by Order, in a performance that is not accepted by the fact that, at the time of issue, Portugal was in a situation of emergency. In fact, under the terms of Article 19, paragraph 7 , of the CPR, the declaration of a state of emergency cannot affect the application of constitutional rules regarding the competence and functioning of sovereign bodies. Thus, the invasion of legal domains by administrative powers should not be allowed.

On the other hand, the state of emergency Portugal experienced demonstrated that the procedure of making the laws was able to correspond to the urgency in the normative creation that the situation demanded, through a particularly quick response by the Parliament in relation to the Government's initiatives. There are no reasons to justify the modus operandi adopted and example of this is that it was by law (Law no. 13/2020, of 7 May) that VAT exemption for intra-Community transfers and acquisitions of goods needed to combat the effects of the COVID-19 outbreak by the state and other public bodies or by non-profit organisations was established.

We conclude, then, in this case, that the ends (the tax exemption), do not justify the means (the exemption established without having passed the scrutiny of the Parliament.

The fact we point out a concrete case in which an exemption from VAT was instituted without regard to the legality requirements, serves to emphasise the relevance that the principle of legality assumes in tax matters - particularly in essential matters -, still in a context of a constitutional state of exception. The relevance of the topic justifies that it be addressed in this context, in order to contribute to the removal of possible future approaches that put bankrupt fundamental pillars over rule of law, which seems not to be affected in pandemic situations.

\section{Conclusive lines}

The reaction to COVID-19 determined the adoption of legal-normative prescriptions by the European Union, of a tax nature, in order to contribute to the

of December 31 (paragraph c) was introduced by Law no. 36/2016, of November 21). 
mitigation of the negative effects resulting from the pandemic, prescriptions that were essentially guided by extraordinary, exceptionality and transience.

However, it does not serve to justify a normative "downgrade". The circumstance of being faced with measures that do not appear, at least until now, as current or usual and that, also for this very reason, represent exceptions from the regimes are, in ordinary or normal circumstances, the rule. Constitutional powers cannot, therefore, be disregarded for reasons of exceptionality. If constitutional requirements are not respected, the normative acts created will be unconstitutional, with resulting consequences. Representativeness in tax matters - guaranteed by issuing the appropriate legislative acts - should not be restricted. In fact, experience shows that the terms of ordinary legislative creation are able to guarantee speed.

On the other hand, especially with regard to transience, although, at times, it was concluded that the means adopted were justified by the objectives to be achieved, we cannot fail to point out that no European (and national, also) legaltax instrument of "crisis" was designed to concretely meet a pandemic such as that caused by COVID-19. It is concluded, therefore, that it is to be envisaged, in terms of the Law to be constituted, and in the face of threats that scenarios with similar contours may present, the establishment of legal-normative solutions that tend to cover factual contexts do not, in fact, sympathise with short duration measures.

Nevertheless, and in general terms, the balance, regarding the measures studied here, is positive, especially given the demanding task of legislators in catastrophic situations, which require special consideration between the various legal assets and public and private interests - present and future - that may be in conflict. 